\title{
DESCRIPTIONS OF SPIDERS OF THE GENUS SYNAGELIDES (ARANEAE: SALTICIDAE) FROM JAPAN AND NEPAL
}

\author{
By \\ Andrzej Bohdanowicz \\ Zaklad Zoologii Stosowanej IBS, Poland
}

Synopsis

Bohdanowicz, A. (Zaklad Zoologii Stosowanej IBS, WSRP, Prusa 12, 08100 Siedlce, Poland): Descriptions of Spiders of the Genus Synagelides (Araneae: Salticidae) from Japan and Nepal. Acta Arachnol., 28: 53-62 (1979).

This paper gives a comparative description of Synagelides agoriformis Strand in Bösenberg et Strand, 1906, S. annae sp. n. from Japan and $S$. nishikawai sp. n. from Nepal.

Owing to kind assistance and advice of Prof. T. Yaginuma and Mr. Y. NishikAWA I have been able to study s collection of Japanese Synagelides, containing both sexes of $S$. agoriformis and one new species. At this opportunity, I describe another new species from Nepal, too.

The genus Synagelides STRAND in BöSENBERG and STRAND, 1906, considered heretofore a monotypic one, is identical with the genus Tagoria ScHENkEL, 1963, and contains at present 7 species, distributed in Primorie (USSR), Japan, Korea, China, Bhutan and Nepal. Out of these, 4 species have been discovered and described during the year 1978 (the papers quoted in references).

Reproductive apparatus in Synagelides presents in both sexes an exceptional structure, easily identifying the genus, but rather difficult to interprete affinities.

As the type species of the genus, S. agoriformis, has been described from Japan (without precise locality), the Japanese species of this genus are of

Results of the Himalaya Expeditions of J. MARTENS, No. 61-No. 60: Senckenbergiana biol., 60 (1/2) : 115-130, 1979.-J. M. sponsored by Deutscher Akademischer Austauschdienst and Deutsche Forschungsgemeinschaft. 
special importance.

The 令 S. agoriformis has been known from Primorie only (PRószYŃSKI, in print) and the ovservations of Mr. NishikAWA on mutual occurrence of similar $\hat{O}$ with a typical S. agoriformis 우 (personal communication from Prof. T. Yaginuma) confirms their conspecific status.

The shape of these spiders has some ant-like features, and Prof. T. YAGINUMA and Mr. NISHIKAWA state that sometimes they were collected nearby ant nests (personal letter). It is therefore interesting to find out whether there is any biological relationships with ants.
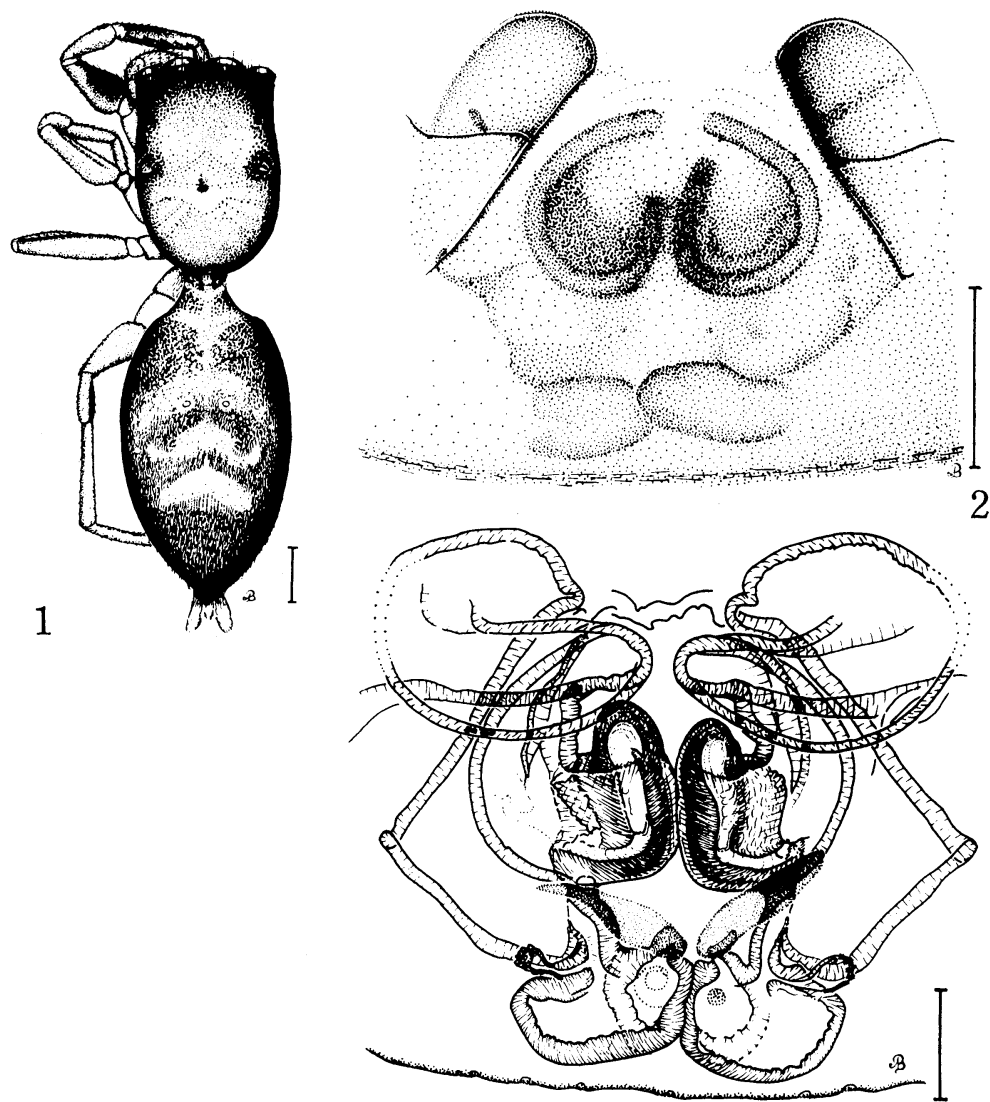

Figs. 1-3. Synagelides agoriformis STRAND in Bösenberg et STRAND, 1906 우 : 1-dorsal view of the spider, 2-epigyne, 3-epigyne after maceration. 
Synagelides agoriformis STRAND in BÖSENBERG et STRAND, 1906

Material from Japan: 1 h holotype-Synagelides agoriformis STRAND, Japan, leg. Dönitz (SMF 2632-Frankfurt a. M.) ; 2우 우, 4소, Imazu-cho, Shiga Pref. coll. Y. Nishikawa, 5-IV-1977; 1우, 1令 Minoo, Osaka Pref., coll. Y. Nishikawa,

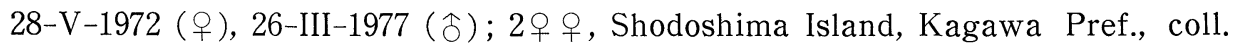

T. Yaginuma, 4-IV-1955.

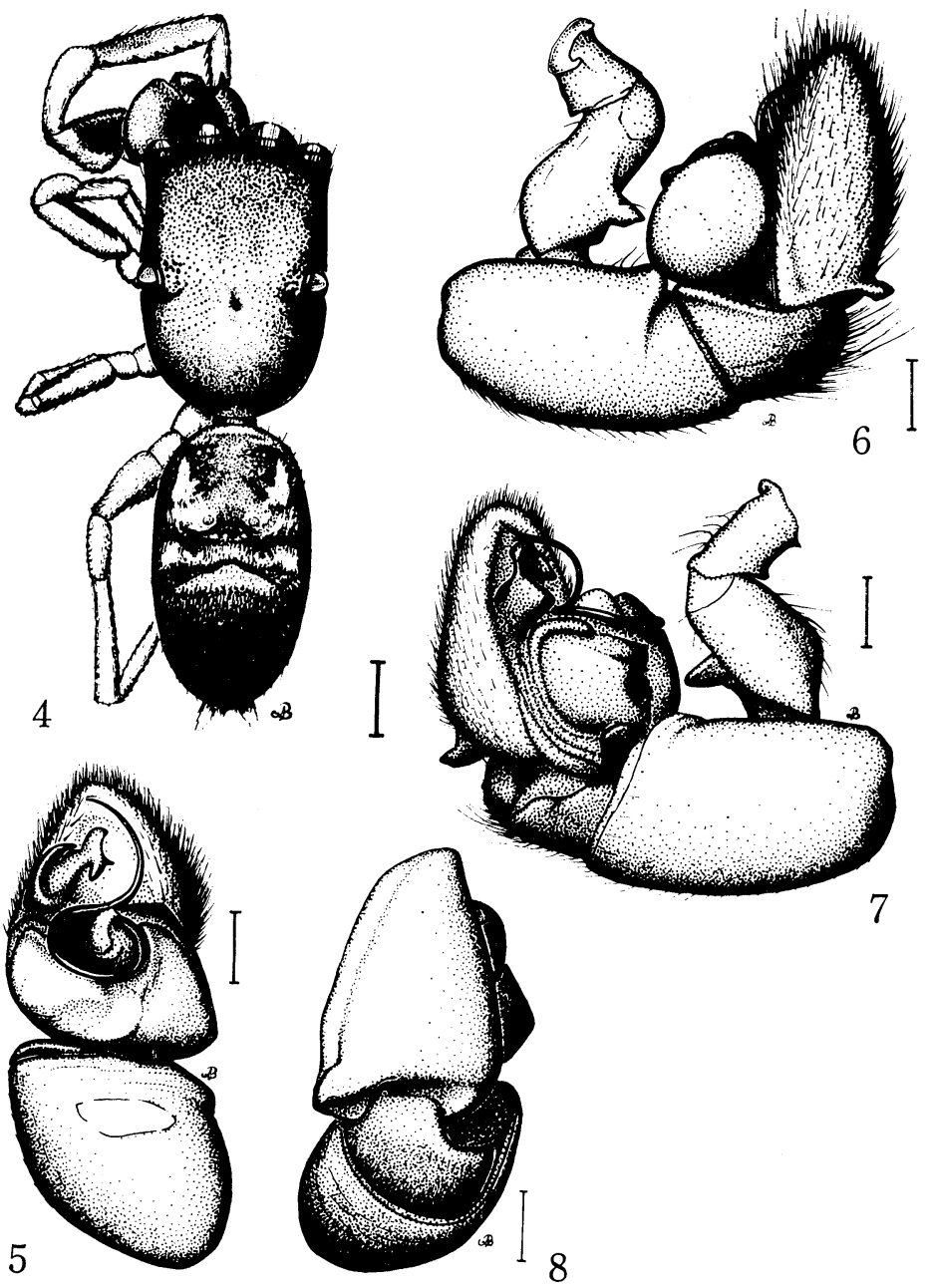

Figs. 4-8. Synagelides agoriformis, ô:4-dorsal view of the spider, 5-8 right palpal organ. 
The general appearance is shown on Figs. 1 (ㅇ) and 4 ( $\hat{\delta}$ ). The epigyne and its internal structure are shown on Figs. 2-3, the appearance of palpal organ of male on Figs 5-8. The external appearance of epigyne differs distinctly from all other species except the new species which is now being described by Dr. PrószYŃSKI (PrószYŃSKI, in print).

Male is characterized by absence of tibial apophysis and special development of posterior surface of cymbium, the dorsal surface of cymbium is shortened.

Outside Japan S. agoriformis is known from North Korea and Primorie, USSR.

\section{Synagelides annae sp. $\mathrm{n}$.}

Material: 1ㅇ holotype, 1\} allotype, $1 \hat{\delta}$ paratype, Mt. Hikosan, Fukuoka Pref., Japan, coll. Miss C. OKuma, 27-VIII-1959.

Type depository: The holotype is in the collection of the Arachnological Society of East Asia (Osaka, Japan).

\section{Description of female}

Dorsal aspect: Cephalothorax yellow-fawn, eye-field dull yellow and wrinkled. Eye-surroundings intense black, behind anterior eyes there is a row of light medially bent setae and longer brown hairs. Ventral margin of carapace dark-brown. Length of cephalothorax 1.51, length of eye-field 0.95 , width of eye-field I 1.07, width of eye-field II 1.05 .

Legs uniformly yellow, metatarsus and tibia I a little darker, with four $(2+2)$ spines on metatarsus I, on tibia I 4 pairs of spines, three distal pairs reaching almost the distal end of tibia (Fig. 11). Length of segments of legs: I $0.35+0.37+0.82+0.72+0.82$, II $0.30+0.46+0.48+0.40+0.52$, III $0.30+0.62+0.48+$ $0.37+0.65$, IV $0.40+0.87+0.77+0.47+0.87$.

Abdomen of the specimen shrunken, its colour pattern: on dark grey background covered with small pale spots there is a light, broad longitudinal band and a narrow white line on each side, three belts are connected together at about three-fifth of lenfth of abdomen by a transverse light band. Sides also dark grey with fine longitudinal pale dotted lines. Anal tubercle and spinnerets pale yellow. Length of abdomen 2.22 .

Frontal aspect: Clypeus darkbrown. Chelicerae yellow (their dentition on Fig. 12, similar to that in S. agoriformis). Pedipalps uniformly pale yellow. 

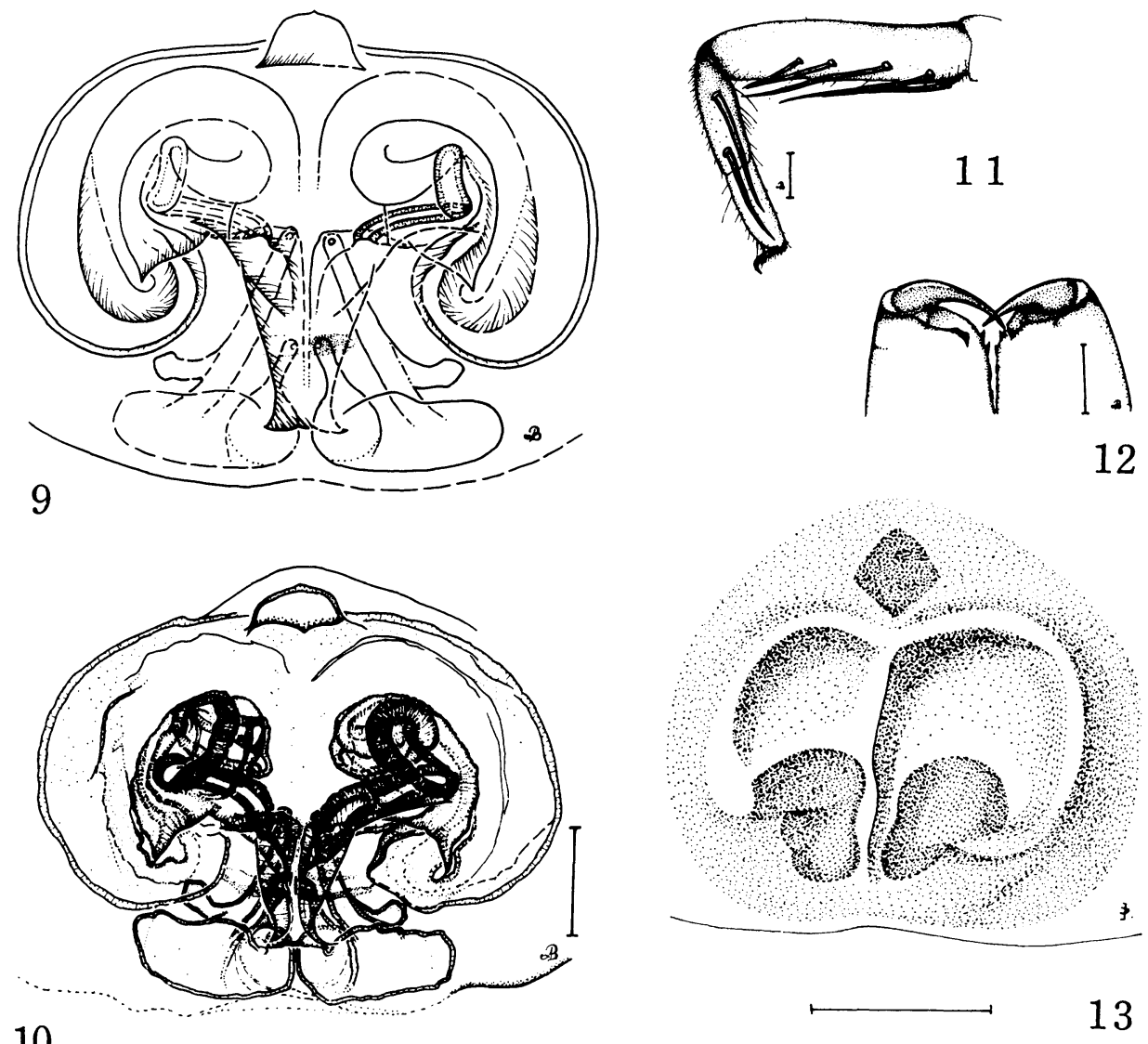

10

Figs. 9-13. Synagelides annae sp. n., holotype 오: 9-simplified, diagram of epigyne (upper structures left, deeper ones right side), 10-epigyne after maceration, 11prolateral view of right leg I, 12-posterior view of chelicerae, 13-epigyne.

Ventral aspect: Sternum yellow to yellowish grey with sparse setae, bordered with a distinct brown line. Abdomen light grey. Epigyne resembles that in Synagelides cavaleriei (SchenKel, 1963) (=Tagoria c.) and two other species from Bhutan, but differs from them in details of both external appearance and internal structures, as shown on Figs. 9-10, 13.

\section{Description of male}

Dorsal aspect: Cephalothorax dark brown, eye-field fawn and wrinkled. Eye-surroundings and ventral margin of carapace same as in female. Behind 
anterior eyes there is a row of scattered whitish medially bent setae and longer brown bristles. Length of cephalothorax (allotype-paratype) 1.50-1.40, length of eye-field $0.87-0.82$, width of eye-field I $1.05-1.02$, width of eye-field II $1.07-1.02$.

On both specimens legs I are missing, Legs II-IV yellow with tarsus and metatarsus yellowish-fawn. Inconspicuous dark streaks on both lateral surfaces of tibia, patella and femur of legs III and IV. Length of segments of legs:
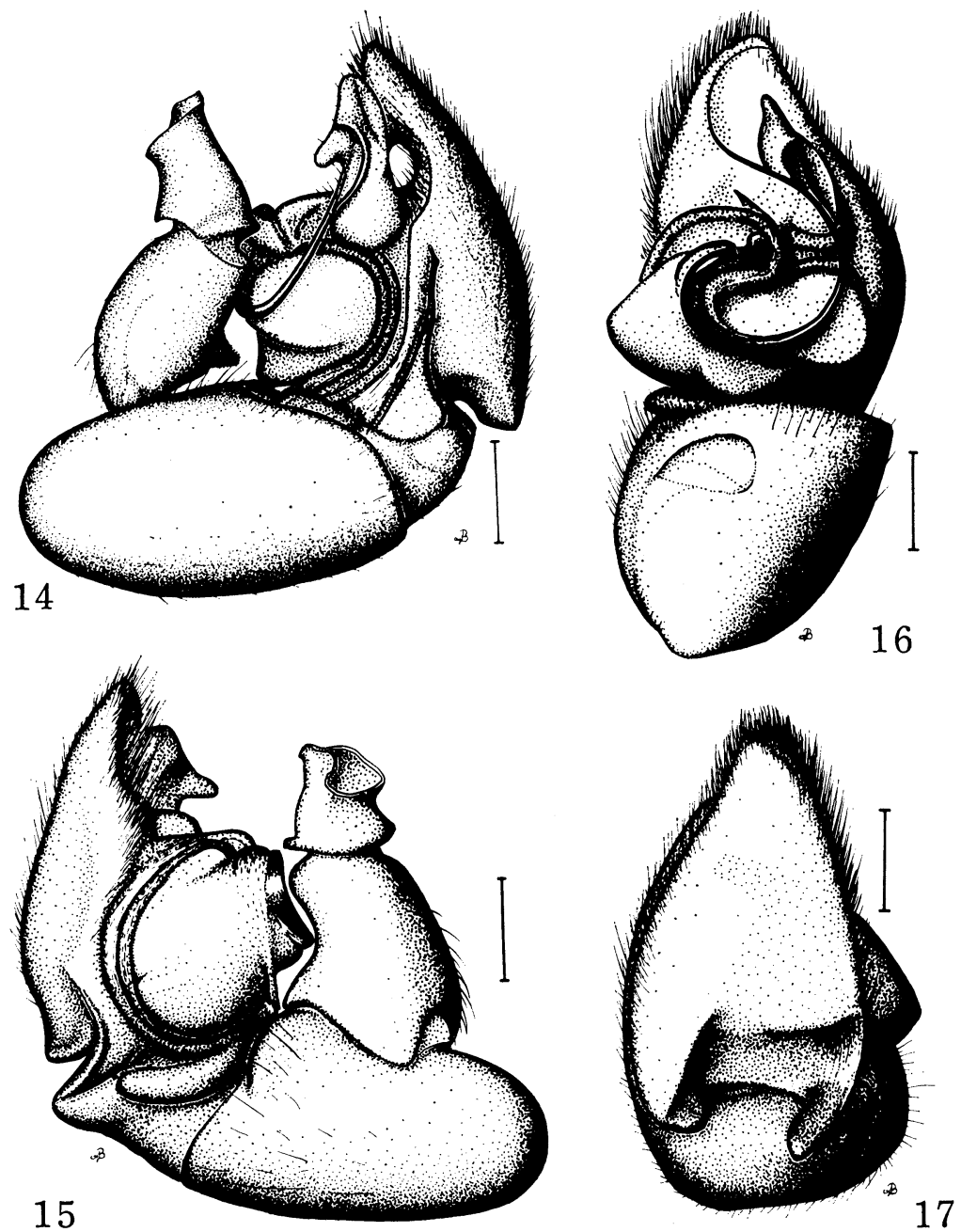

Figs. 14-17. Synagelides annae sp. n,, allotype, 合: left palpal organ. 
II (paratype) $0.27+0.45+0.40+0.40+0.62$, III (allotype-paratype) $0.30-0.30+0.57$ $-0.52+0.47-0.42+0.32-0.32+0.72-0.62$, IV $0.35-0.35+0.77-0.75+0.75-0.67+$ $0.45-0.40+0.80-0.72$.

Abdomen generally dark grey with smal pale spots, anteriorly with a big lighter yellowish spot and two white longitudinal lines on both sides reaching three-fifth of length of abdomen. Lateral surfaces as in S. agoriformis. Anal tubercle light. Length of abdomen 1.47-1.42.

Frontal aspect: Clypeus narrow, dark brown. Chelicera dark yellow with a bifid tooth on inner posterior margin. Teeth on inner anterior margin resembling those of female. Palpal organ with long tibial apophysis, appressed to cymbium, with triangular basal part and narrow apical half. Dorsal surface long, with long posterior processes (Figs. 14-17).

\section{Synagelides nishikawai sp. n.}

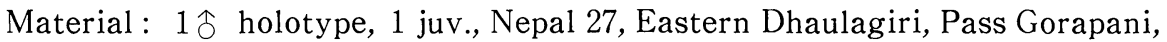
$3130 \mathrm{~m}$ alt., leg. J. Martens, 11-XII-1969, (SMF. 30320-Frankfurt a. M.)

In the aspect of the wale specimen, the species possesses features intermediary between other Synagelides and other Salticids, and has therefore some importance for explanation of possible origin of the peculiar features of this genus. The species seems to be related with the ancestrals of the group rather than being a representative of some new branch.

\section{Description of male}

Dorsal aspect: Cephalothorax fawn, eye-field distinctly convex (Fig. 23) whilst flat in other species, wrinkled with a gold metallic shade, anteriorly black to blackish-fawn posteriorly. The eye rims of both pairs of eyes of first row with a metallic blue-green gleam; setae as in others. Ventral margin of carapace dark brown. Length of cephalothorax 1.67, length of eye-field 0.90, width of eye-field I 1.05, width of eye-field II 1.05 .

Leg I: metatarsus and patella yellow, other segments dark fawn. Spines: $2+2$ on metatarsus and 3 pairs on tibia. On legs II similar but weaker and more irregularely arranged spines: left-metatarsus $2+2$, tibia $1+1$, right$2+1$ on retrolateral surface, no spines on tibia. Legs II-IV yellow-fawn, with dark pro- and retrolateral surface of femur. Length of segments of legs: I $0.42+0.62+0.92+0.87+1.25$, II $0.32+0.52+0.55+0.50+0.80$, III $0.35+0.72+0.55+$ $0.42+0.72$, IV $0.42+0.97+0.87+0.50+1.07$ 
Abdomen generally grey to blackish at anterior and posterior ends with a lighter herringbone pattern and two colour patches: orange-grey anteriorly and orange-brown posteriorly (Fig. 25). Laterally to anterior end small tufts of white, appressed, flattened setae, some of them scattered backwards. There
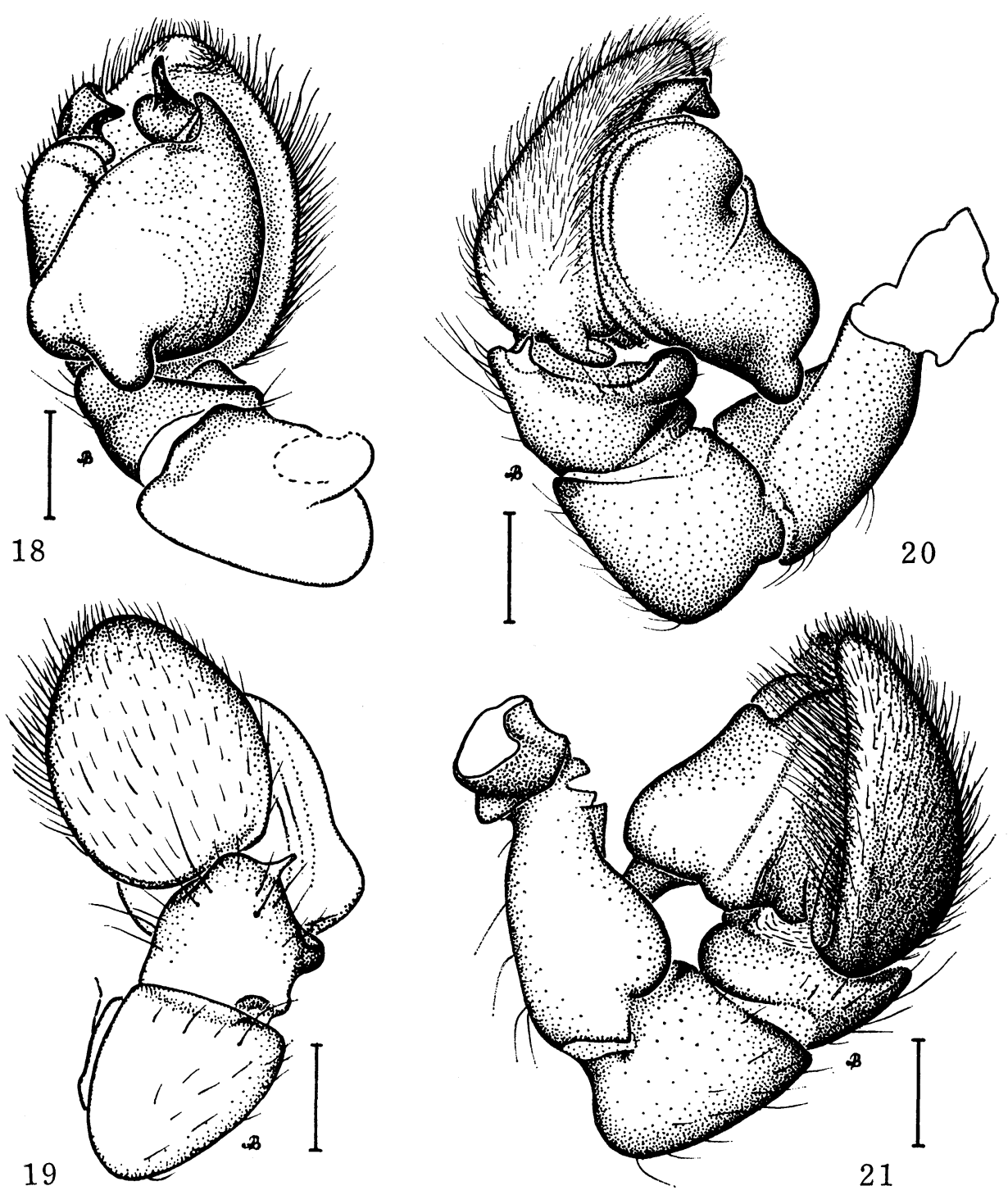

Figs. 18-21. Synagelides nishikawai sp. n., holotype $\hat{0}$ : right palpal organ. 
are narrow longitudinal lines on lateral surface. Anal tubercle and spinnerets light yellow. Length of abdomen 1.87 .

Frontal aspect: Clypeus blackish brown, narrow. Chelicera with a bifid tooth on inner posterior margi.n
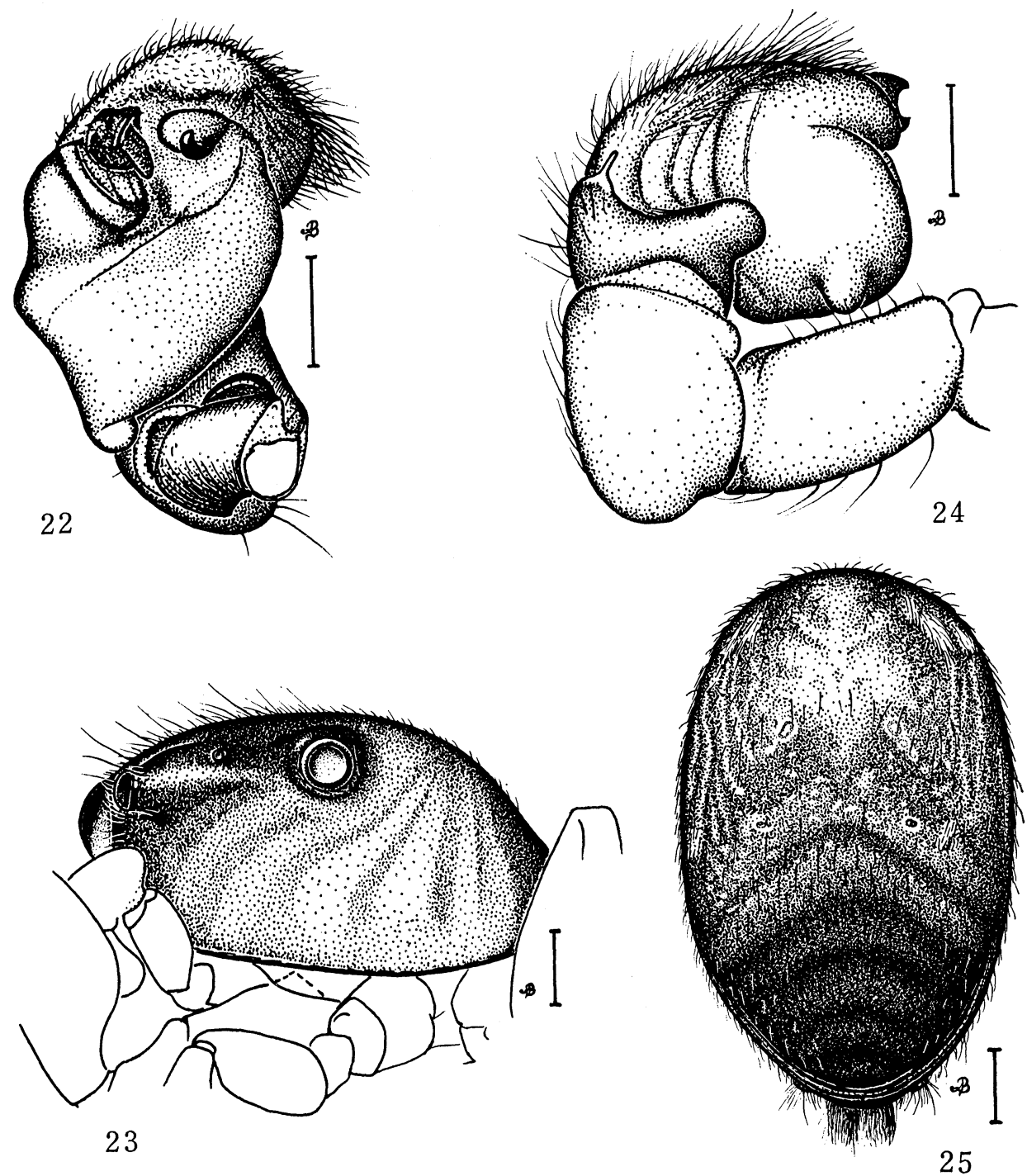

Figs. 22-25. Synagelides nishikawai sp. n., holotype $\hat{\delta}: 22$, 24-right palpal organ, 23-carapace from the left, 25-dorsal view of abdomen. 
Pedipalp specific (Figs. 18-22, 24): general arrangement of joints like in other Synagelides, but the unusual proportion of swollen patella to reduced femur is less striking here. Other differences: femur has no hook-like process, patella much shorter, tibio-tarsal articulation more simple, tibial apophysis small and weak, bulbus elongated, its hooked process small and weakly developed, embolus strikingly different, located apically, short and bulged laterally at its base.

Ventral aspect: Sternum yellow, bordered browm. Abdomen light, with radial grey patches and a narrow fold near spinnerets.

Female unknown. As the interpretation of epigyne is rather difficult in Synagelides, study of it in S. nishikawai seems to be promising in explanation of functions of particular structures and their mutual correlation in both sexes.

The young specimen generally similar to the male, but more thickset.

摘要

A. ボーダノビチ (Zaklad Zoologii Stosowanej IBS, WSRP, Pursa 12, 08100 Siedlce, Poland)：日本拉よびネパール産 Synagelides 属ハェトリグモ 2 新種の記載。

BöSENBERG u. STRAND (1906) 中に記載された Synagelides 属の模式種 S. agoriformis STRAND と比較しながら, 日本産の 1 新種 S. annae およびネパール産の 1 新種 S. nishikawai を記載した。

\section{References}

Bohdanowicz, A. 1978. Araneae: Fam. Salticidae, Genus Synagelides. Ergebnisse der Bhutan-Expedition 1972 des Naturhistorischen Museums in Basel. Entomologica Basiliensia, Basel, 3.8 pp. $11 \mathrm{ff}$ (in print).

- (in print). Genus Synagelides, Bösenberg et STrRand, 1906 in Nepal (Salticidae, Aranei). Senckenbergiana biol., Frankfurt a. M.

\& HecIAK, S. (in print). Redescriptions of two species of Salticidae (Aranei) from China. Ann. zool., Warszawa, 11 pp (typescript), $19 \mathrm{ff}$.

— \& Proszynski, J, (in preparation). Systematic studies on East Palaearctic Salticidae (Aranei). V Salticidae of Japan.

Proszynski, J. (in print). Systematic studies on East Palaearctic Salticidae. III. Remarks on Salticidae of the USSR. Ann. zool., Warszawa, 34 pp. 324 tt.

Wesolowska, W. (in print). Salticidae (Aranei) from North Korea, China and Mongolia. Ann. zool., Warszawa. 37 pp. (typescript), $112 \mathrm{ff}$. 